\title{
Embryogenic Callus Induction of Pencil Orchid (Papilionanthe hookeriana Rchb.f.) Through in Vitro Culture
}

\author{
A. Romeida ${ }^{\#}$, D.W. Ganefianti" ${ }^{\#}$ Rustikawati $^{\#}$ \\ \# Agriculture Faculty, Bengkulu University, Bengkulu 38000, Indonesia \\ E-mail: atra30@gmail.com
}

\begin{abstract}
Papilionanthe hookeriana Rchb.f. (Orchidaceae), popularly known as 'Pencil orchid' in Indonesia, is a perennial ephiphyte orchid, found only at Dendam Tak Sudah Lake in Bengkulu. The aims of this research were to find the best sterilization technique of $P$. hookeriana explant and to induce maximum formation of embryogenic calli. Rapid multiplication of this orchid was achieved through culture of shoot tips and young leaf segments of mature plants by in vitro cultured on Murashige and Skoog (MS) basal medium enriched with $50 \mathrm{~g} \mathrm{~L}^{-1}$ banana pulp. The experiment used Completely Randomized Design (CRD) with three replications. In the first stage, the explants were sterilized using three compositions of sterilizaton material. In the second stage, the explants were planted on the MS basal medium with addition of five levels of 2,4-Diclhorophenoxy Acetis Acid concentrations, namely $0,0.25,0.50,0.75$, and $1.00 \mathrm{mg} \mathrm{L}^{-1}$. The result showed that the best sterilization method to reduce explant contaminant was method 3 , in which the explant was washed with detergent, rinsed with flowing water, soaked in $0.1 \%(\mathrm{v} / \mathrm{v}) \mathrm{HgCl}_{2}$ solution for $30 \mathrm{minutes}$, soaked again in the $10 \%(\mathrm{v} / \mathrm{v})$ Sodium hypochloride solution for 20 minutes, rinsed three times with sterile water before planted and then soaked in sterile water added $10 \%(\mathrm{v} / \mathrm{v})$ betadhine before planted on treated medium. This method was able to reduce contamination levels up to $70 \%$ from explants cultured for 5 months on MS medium. MS medium added with 1.00 mg $\mathrm{L}^{-1} 2,4-\mathrm{D}$ produced the highest number of embryogenic calli, and the biggest callus diameter $(3.5 \mathrm{~cm})$, characterized by transparent green color and friable callus structure.
\end{abstract}

Keywords - 2.4-D; Papilionanthe hookeriana; orchid; sterilization; callus; in vitro

\section{INTRODUCTION}

Bengkulu province has abundant orchid germplasm source. The source of germplasms are in protected forest, National park and nature reserve. Based on Romeida's result research [1], among 164 wild and domesticated species of Bengkulu nature orchid, there was Pinsil orchid (Papilionanthe hookeriana) which has been rare in its habitat (Dusun Besar Nature Reserve). Now P. hookeriana is one of orchid species protected by Indonesian government regulation no 7, 1999 regarding preservation of wild plant and animal species.

Unfortunately, many orchids are threatened with extinction because of environmental degradation, human occupation of natural habitats, and over exploitation for horticultural and ethnobotanical uses [2]. Habitat destruction due to road construction, fire, urbanization, drainage, and other anthropogenic influences can also directly affect these plants [3]. The number of orchid species is rapidly and steadily declining because of their low rate of natural propagation and the ongoing collection from nature [4], [5], and [6]. Careless collection of these species has led to serious genetic and ecological erosion; many have already been listed as endangered species [7], [8], and [9].

$P$. hookeriana orchid is an epiphyte orchid. The plant growth type is monopodial. This orchid is very similar to $P$. Teres from Thailand, so that is difficult to distinguish between the two orchids if there are seen from appereance only. In the natural habitat, the orchid grows well until 2.5 $\mathrm{m}$ high. The stem is cylindrical-rounded, segmented and covered with thin sheath. The stem diameter is around $0.5-$ $1.2 \mathrm{~cm}$ The leaf is a cylindrical with acute tip and stand-up similar to pencil. The surface of steam and leaf are green. The roots appear at the node of steam. So, the orchid can be reproduced with stem cutting [3].

$P$. hookeriana scarcely produces fruits in the nature habitat. Fertilization can occur when it is assisted by insects or human. If the seeds are produced, they can not germinate in the natural habitat, because they do not have endosperm in their seeds, so, the germination rate is only around $1 \%$ in their habitats [10].

Propagation of this orchid through in vitro technique is one alternative to overcome the low germination rate in the natural habitat. In vitro culture can produce a lot of seedlings within short time period. For in vitro propagation, 
we can use seeds and young steam leaf or shoot tip explant sources [11]. In its habitat, $P$. hookeriana needs Crinum aciaticum as a wet stem plant support so it can grow up right, but it does not take up the mineral nutrient from the Crinum.

In Sumatera island this orchid is found only in Bengkulu and Bangka Belitung [12]. In the Bengkulu province, it is found only in Dusun Besar Nature Reserve (DBNR) registered No. 602/Kpts-II/1992 by Forestry Ministerial decree which is established as orchid conservation area. However, this species is threatened to the brink of extinction because of habitat degradation, theft and encroachment. It is listed in Apendix 1 of CITES in 2013 and The IUCN Red List of Threatened Species. For breeding, Natural Resources Conservation Center (NRCC) has difficulty to find this orchid in their habitat. At the end of 2002, only one plant was found which was used as source for propagation. In 2005, 36 more plants were found. Bengkulu province NRCC was able to propagate the plants into 365 plants until 2008 and then they were plantled outside its natural habitat. However, because the climate and habitat for nursery were not suitable for growing this orchid, the population decreased continuously. So, in 2011 only 15 plants survived. In the end of $2011 \mathrm{NRCC}$ returned 10 plants to their natural habitat.

Acording to Bengkulu Antara News [13], Vanda Miss Joaquim (the Singapore's national flower) is crossing between $P$. hookeriana (from NRCC Bengkulu, Indonesia) with $V$. teres (from Thailand). Another famous breed of $P$. Hookeriana is $V$. cooperi which is the result of back cross between $V$. Miss Joaquim with $V$. hookeriana. This variety of this orchid has not been studied comprehensively, because it needs long time for reseach and costumers prefer hybrid orchids that have many variations.

The success of in vitro orchid propagation depends on sterilization methods used. This orchid grows above the surface of swamp so the plants have many diease agents such as fungi and bacteria. To be used the in vitro explant, the plants must be sterilized using some techniques and stages.

Seed sowing on in vitro culture medium is an orchid propagation standard. Each species of orchid requires different medium composition, depending on the type of explants used. To accelerate and direct the growth and multiplication of explants, addition of plant growth regulator (PGR) into the planting medium is needed. The use of 2,4-D has been reported for embryogenic callus growth induction. The highest callus weights on Sorbon Lili variety which used the flower stalk explants was produced on the MS + $0.2 \mathrm{mg} \mathrm{L}^{-1} \mathrm{TDZ}+0.05 \mathrm{mg} \mathrm{L}^{-1}+2,4-\mathrm{D}+0.3 \mathrm{mg} \mathrm{L}^{-1}$ kinetin medium [14]. The highest multiplication crossing Vanda tricolor $\mathrm{x}$ Vanda Pteroceras var. Validum seeds is generated on MS medium adding 2\% activated charcoal, 150 $\mathrm{g} \mathrm{L}^{-1}$ banana Ambon pulp, 5 ppm kinetin and 1 ppm 2,4-D [15]. (Romeida and Yuliasari. 2003)15.

Acording to [16] the highest embryogenic calli can be formed from root tips and cut of stem tip and leaf segments on 1/4 MS bassal medium suplemented with $0.1-3 \mathrm{mg} \mathrm{L}^{-1}$ TDZ and 3 - $10 \mathrm{mg} \mathrm{L}^{-1}$ 2,4-D for 4 weeks.

Some of Vanda's genus need different types of plant regulator to propagate their explants. Shoot tips $(0.5-0.8$ $\mathrm{cm}$ in length) of Blue Vanda (Vanda coerulea) cultured on
Mira media responded with direct formation of 3-12 shoot buds per explant in 12 weeks. The highest number of shoot (70 -100 shoots per explant) had pruced on medium Mira enriched with $35 \mathrm{~g} \mathrm{~L}^{-1}$ banana pulp, $30 \%$ coconut water and $1,08 \mu \mathrm{M}$ NAA after 30 weeks of culture [25]. The endangered Blue Vanda is specific Vanda from located in Sri Lanka that has a beautiful flower (The IUCN Red List of threatened species too) [17].

Embryogenic callus of Hibiscus sabdariffa was produced from 0.01 to $0.05 \mathrm{mg} \mathrm{L}^{-1}$ of 2,4 - D concentration [18]. The enhanced 2,4-D and Banana pulp on medium Vacin and Went (VW) was able to induce embryogenic callus on many species of orchids espesially for Phalaenopsis sp. [19].

This experiment was done in two stages. The first stage of experiment aimed to get the best sterilization method to effectively reduce many contaminants from young leaf segment of $P$. hookeriana used as explants. The second one was induced the embriogenic calli using five levels of 2,4-D concentration that can be developed to protocorm Like Bodies ( PLBs).

\section{MATERIALS AND METHODS}

This research was done in two stages. The first stage was the effect of several sterilization methods to reduce $P$. hookeriana explants' contaminant level. The second one was in vitro embryogenic calli induction of $P$. hookeriana through several 2,4-D concentrations.

\section{A. The effect of several sterilization methods to reduce $P$. hookeriana explants' contaminant level}

This research was done in the Tissue Culture Laboratory, Agriculture Faculty, Bengkulu University, Indonesia in 2013. The explant used in this research was collected from plant growing at the orchid plant breeding nursery and farm located near the DBNR Bengkulu Province.

In the first stage, the explants were sterilized using three compositions of sterilant. The young leaves of $P$. hookeriana were sterilized with three sterilization methods. The chemical compound used in that methods consisted of Agrept, previcur $\mathrm{N}$, Benlate, $\mathrm{HgCl}_{2}$, Sodium hypochloride, and Bethadine. They were combined into three compositions and stages of sterilizations (Table 1). The young leaves of $0.5 \mathrm{~cm}$ in length used as explants had been sterilized then planted on MS Medium that was supported by $20 \mathrm{~g} \mathrm{~L}^{-1}$ sucrose without PGR (Fig. 1). Data collected were contaminant percentage, types of contaminated microorganism and survival rate of explant.

\section{B. In Vitro Embryogenic Calli Induction of P. hookeriana Using Several 2,4-D Concentrations}

In the second stage, the sterile explants (resulted from the first experiment) were planted on surface of Murashige and Skoog (MS) basal medium suplemented with myoinositol (100 $\left.\mathrm{mg} \mathrm{L}^{-1}\right)$, pyridoxine $\mathrm{HCl}\left(5 \mathrm{mg} \mathrm{L}^{-1}\right)$ thiamine $\mathrm{HCl}(1 \mathrm{mg}$ $\left.\mathrm{L}^{-1}\right)$, glycine $\left(2 \mathrm{mg} \mathrm{L}^{-1}\right)$, coconut water $(15 \% \mathrm{v} / \mathrm{v})$, and sucrose $\left(20 \mathrm{~g} \mathrm{~L}^{-1}\right)$ recomended by [20] and [21], The $\mathrm{pH}$ of media was adjusted to 5.8 with $1 \mathrm{~N} \mathrm{NaOH}$ and $\mathrm{HCl}$. Medium was sterilized using autoclave for 20 minutes at $121^{\circ} \mathrm{C}$ and 15 psi at pressured. The experimental used Completely Randomized Design (CRD) with five levels of 2,4Diclorophenoxy acetic acid (2,4-D) concentrations, namely 0 , 
$0.25,0.50,0.75$, and $1,00 \mathrm{mg} \mathrm{L}^{-1}$. Every treatment consisted of three replications. Three explants were plantled in each culture bottle, so the total experimental unit was 45 bottles. Data observed were explant color, explant development, callus quality, callus quantity, callus diameter, callus color and callus proliferation.

TABLE I

Stages of Sterilization Methods Using SeVERAL SteriLANT COMPOSITION

\begin{tabular}{|c|c|}
\hline Methods & $\begin{array}{l}\text { Specification of compositions and } \\
\text { stages of sterilization }\end{array}$ \\
\hline M1 & $\begin{array}{l}\text { The explant was washed with detergent, rinsed } \\
\text { with flowing water, soaked in } 2 \mathrm{ml} \mathrm{L}^{-1} \text { Previcurl } \mathrm{N} \\
+2 \mathrm{~g} \mathrm{~L}^{-1} \text { Agrept for } 1 \text { hour, soaked with } 10 \% \\
\text { (v/v) Sodium hypochloride solution for } 20 \\
\text { minutes, rinsed three times with sterile water } \\
\text { before planted then soaked in sterile water added } \\
10 \%(\mathrm{v} / \mathrm{v}) \text { betadhine before planted on treated } \\
\text { medium. }\end{array}$ \\
\hline M2 & $\begin{array}{l}\text { The explant was washed with detergent, rinsed } \\
\text { with flowing water, soaked overnight } 2 \mathrm{ml} \mathrm{L}^{-1} \\
\text { Previcur } \mathrm{N}+2 \mathrm{~g} \mathrm{~L}^{-1} \text { Benlate, rinsed three times } \\
\text { with sterile water before planted then soaked in } \\
\text { sterile water added } 10 \%(\mathrm{v} / \mathrm{v}) \text { betadhine before } \\
\text { planted on treated medium. }\end{array}$ \\
\hline M3 & $\begin{array}{l}\text { The explant was washed with detergent, rinsed } \\
\text { with flowing water, soaked on } 0.1 \%(\mathrm{v} / \mathrm{v}) \mathrm{HgCl}_{2} \\
\text { solution for } 30 \text { minutes, soaked again on } 10 \%(\mathrm{v} / \mathrm{v}) \\
\text { Sodium hypochloride solution for } 20 \text { minutes, } \\
\text { rinsed three times with sterile water before planted, } \\
\text { then soaked in sterile water added } 10 \%(\mathrm{v} / \mathrm{v}) \\
\text { betadhine solution before planted on treated } \\
\text { medium. }\end{array}$ \\
\hline
\end{tabular}
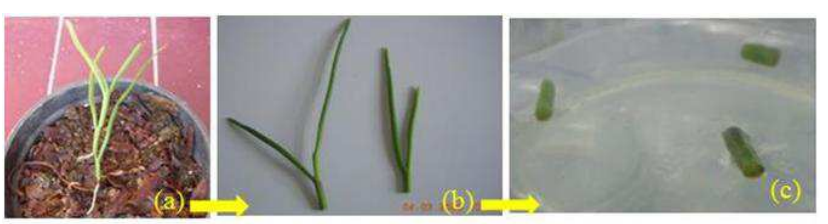

Fig. 1 Explant used (young leaf segment of $P$. hookeriana: (a) plant $P$. hookeriana ochid 2 years old, (b) young leaves, (c) explant (segment of leaf $0.5 \mathrm{~cm}$ in length

\section{RESULTS AND DISCUSSION}

\section{A. The effect of several sterilization methods to reduce $P$. hookeriana explants' contaminant level}

The observation at 5 months after planted on MS medium, young leaf explants orchid $P$. hookeriana previously sterilized using three methods produced different responses depending on the methods which were used (Table 2).

The observation of the three methods of sterilization used, sterilization gradually used method 3 tThe explant was washed with detergent, rinsed with flowing water, soaked on $0.1 \%(\mathrm{v} / \mathrm{v}) \mathrm{HgCl} 2$ solution for 30 minutes, soaked again on $10 \%$ (v/v) Sodium hypochloride solution for 20 minutes, rinsed three times with sterile water before planted, then soaked in sterile water added $10 \%(\mathrm{v} / \mathrm{v})$ betadhine solution before planted on treated medium). This methode has produced the highest number of sterile explants and percentage of explants survival up to $70 \%$ (Table 2 ) .
The results of LSD test at 5\% level showed that the percentage of contaminated explants and the percentage of survival explants were significantly different among the three methods used. Although the third method has produced the best response, which was declined in the percentage of explants contaminated but the method 3 contained dangerous chemicals compound that is $\mathrm{HgCl}_{2}$. The use of the sterilant continously can cause accumulation of heavy metal $(\mathrm{Hg})$ in the plant tissues or plant cells. The use of this chemical compound has been banned especially for edible plants, because it can give the negative effect on human health. $\mathrm{HgCl}_{2}$ sterilant can be used only for crops that are not to be consumed, including the ornamental plants.

TABLE II.

The EfFect Of Sterilization Methods On Percentage Of Explant CONTAMINATION AND PERCENTAge OF EXPLANT SuRvival.

\begin{tabular}{|c|c|c|c|c|}
\hline $\begin{array}{c}\text { Sterilization } \\
\text { Methods }\end{array}$ & \multicolumn{3}{|c|}{ Contamination Percentage } & $\begin{array}{c}\text { Survival } \\
\text { explant (\%) }\end{array}$ \\
\hline & Bacterium & Fungi & Total & \\
\hline M1 & 53,34 & 13,33 & $66,67 \mathrm{~b}$ & $33,33 \mathrm{~b}$ \\
\hline M2 & 53,33 & 26,67 & $80,00 \mathrm{a}$ & $20,00 \mathrm{c}$ \\
\hline M3 & 20,00 & 10,00 & $30,00 \mathrm{c}$ & $70,00 \mathrm{a}$ \\
\hline
\end{tabular}

Note : The number that was followed by the same letters in the same column are not significantly different of LSD at $5 \%$ levels

Bacterial contamination occured from day 3 until 2 months after planting, while fungi contamination occured after 1 to 4 months after planting. Bacterial contamination had caused white mucus symptoms around the explants, whereas contamination by fungi had caused symptoms such as threads (hyphae/mycelium) and flour (spores). The hyphae and spores color of a fungus infected P. hookeriana explant orchids were white, grey and black (Fig.2).

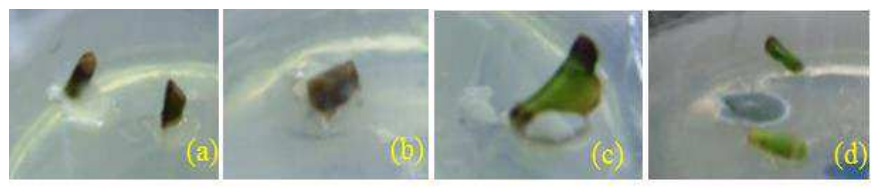

Fig. 2 Contaminants have infected explant young leaf segment of $P$. Hookeriana caused by a. bacterium (white mucus), b. Fungi (white hyphae/mycelium), c. Fungi (grey hyphae/mycelium),

d. Fungi (black hyphae/mycelium)

The highest level of contamination on this research was detected by bacteria, because the $P$. hookeriana orchid had been grown in a high humidity medium, part of the stems submerged in the water. In its habitat, $P$. hookeriana needs Crinum aciaticum that grows in the NRCC area in Bengkulu city as a wet plant support, so it can grow up right.

Water is a the best medium for bacterial growth. Contamination by bacteria is more difficult to eliminate than the contamination caused by the fungi. It is difficult to control bacteria caused by bacteria living inside the cell, while the fungi generally lives on the epidermal layer of leaf tissue and part of the hyphae enters the plant tissue (surface contaminant).

The use of $0.1 \% \mathrm{HgCl}_{2}$ was effective to reduce contamination of explants caused by bacteria and fungi up to $70 \%$ (only $30 \%$ of explants were contaminated). While the use of method 1 caused contamination level higher than method $3(66.67 \%)$. Application of method 2 was ineffective 
to control the bacteria and fungi that contaminated young leaves of explants because the contamination level was very high, up to $80 \%$.

$\mathrm{HgCl}_{2}$ is a kind of poison that can eliminate contaminant directly in case of direct contact with contaminants. Besides eradicating the contaminants, the use of high level $\mathrm{HgCl}_{2}$ concentration can influence the plant cells. Lethal concentrations ranging from 0.60 to $3.519 \mathrm{mg} \mathrm{L}^{-1}$ can kill $95 \%$ of the population Clarias gariepinus [22].

\section{B. In Vitro Embriogenic Calli Induction of P. hookeriana using Several Levels of 2,4-D Concentrations}

The observations of explant development after five months sub-cultured to MS medium enriched with 2,4-D treatment were presented in Table 3.

TABLE III.

EFFECT OF 2,4-D CONCENTRATION TO EXPLANT GROWTH OF P. HoOKeriana Young Leaf Explant At 5 Months AFter Sub Culture

\begin{tabular}{|c|c|c|c|c|c|c|c|}
\hline $\begin{array}{c}2,4-\mathrm{D} \\
\text { Concentratio } \\
\mathrm{n} \\
\left(\mathrm{mg} \mathrm{L}^{-1}\right)\end{array}$ & $\begin{array}{c}\text { explan } \\
\mathrm{t} \text { color }\end{array}$ & $\begin{array}{c}\text { Explant } \\
\text { developmen } \\
\mathrm{t}\end{array}$ & Callus explant & $\begin{array}{c}\text { Callus } \\
\text { Diamete } \\
\mathrm{r}(\mathrm{cm})\end{array}$ & $\begin{array}{c}\text { Callus } \\
\text { Quantity }\end{array}$ & $\begin{array}{c}\text { Callus } \\
\text { Qualit } \\
\mathrm{y}\end{array}$ & $\begin{array}{c}\text { Callus } \\
\text { Proliferatio } \\
\mathrm{n} \text { to PLBs } \\
(\%)\end{array}$ \\
\hline 0.00 & brown & expanded & No callus & 0.00 & $\begin{array}{c}\text { No } \\
\text { callus }\end{array}$ & $\begin{array}{c}\text { No } \\
\text { callus }\end{array}$ & 0 \\
\hline 0.25 & green & callus & white & 1.31 & few & friable & 43 \\
\hline 0.50 & green & callus & $\begin{array}{c}\text { Transparent } \\
\text { green }\end{array}$ & 2.46 & $\begin{array}{c}\text { moderat } \\
\mathrm{e}\end{array}$ & friable & 53 \\
\hline 0.75 & green & callus & $\begin{array}{c}\text { Transparent } \\
\text { green }\end{array}$ & 2.70 & $\begin{array}{c}\text { moderat } \\
\mathrm{e}\end{array}$ & friable & 42 \\
\hline 1.00 & green & callus & $\begin{array}{c}\text { Transparent } \\
\text { green }\end{array}$ & 3.03 & many & friable & 11 \\
\hline
\end{tabular}

Note : PLBs (Protocorm Like Bodies)

The explants grown on MS medium without PGR, expanded 2 months after the sub-cultured had no response yet. At the third month the explants color changed into yellowish, finally the explants became brownish after 5 months. The explant could not develop. The adding of 2,4-D around 0.25 to $1.00 \mathrm{mg} \mathrm{L}^{-1}$ was able to maintain the green color of explants, friable callus quality and transparent green color (Fig. 3). These characteristics showed the embryogenic callus characterictic. The same research result was reported by [23] who have found embriogenic calli on Vanda tessellata orchid.

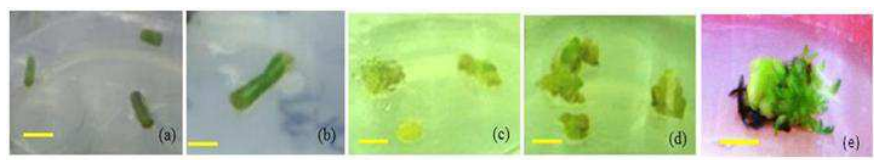

Fig. 3 Callus Quantity . (a) explant (b). No callus formed, (c). a few callus, (d). moderate callus, (d) The bigest callus with PLBs.

Explants development into callus started from the third month after sub-cultured. The quantity and diameter of callus formed were positively correlated with 2,4-D concentration increased up to $1.00 \mathrm{mg} \mathrm{L}^{-1}$. Callus quantity formed following a linear curve $(y=0.745 x-0.334)$ and $R^{2}$ $=0.897$. The resulted of research mean the higher the concentration of 2,4-D applied, the bigger the callus formed. The biggest callus diameter $(3.03 \mathrm{~cm})$ resulted from explants grown on MS medium anriched with $1.00 \mathrm{mg} \mathrm{L}^{-1}$ 2,4-D ( Fig. 4 ).

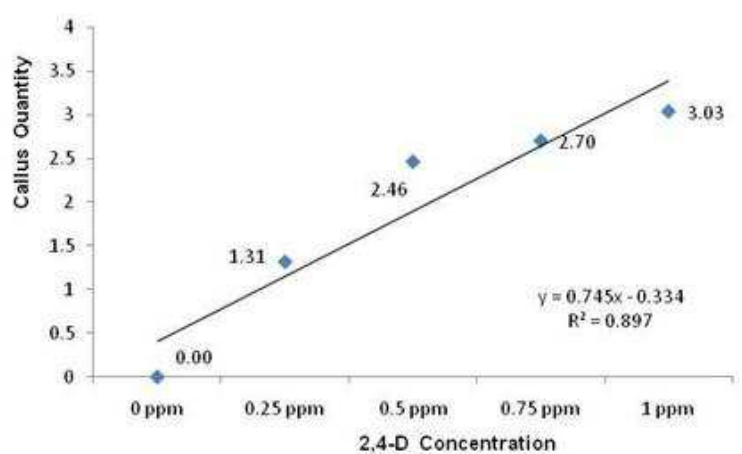

Fig. 4 Effect of 2,4-D Concentrations on P. hookeriana callus diameter

Callus proliferation into Protocorm Like Bodies (PLBs) formed following a quadratic curve $\left(\mathrm{y}=-12.07 \mathrm{x}^{2}+74.52 \mathrm{x}-\right.$ 61 ) and $\mathrm{R}^{2}=0.991$. The highest proliferation rate $(53 \%)$ was produced at the explants grown on MS medium supported with $0.5 \mathrm{mg} \mathrm{L}^{-1}$ of 2,4 - D concentration ( Fig. 5).

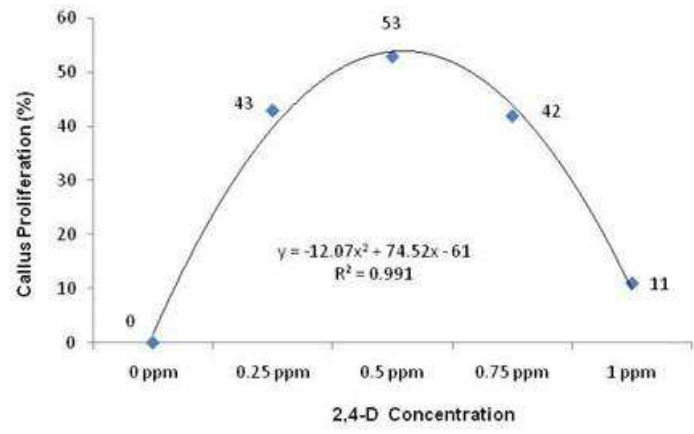

Fig. 5. Effect of 2,4-D Concentration on Proliferation Callus Percentage of $P$. hookeriana developed to PLBs

2,4-D is one kind of auxin group plant growth regulator that is very good for growing callus and root crops, especially when it is used on in vitro culture, but at high concentrations it can cause poisoning as an active ingredient with a systemic herbicide that inhibits the effect of weed growth by accelerating respiration [24] and [25].

This research result is consistent with [18] and [26]. They have studied the regeneration of Red Vanda orchidusing leaf explants (Rhenanthera imschootiana) and Orchid Blue Vanda (Vanda coerulea). Embryogenic callus of Dendrobium microbullon was formed from 4 to 8 months after planted on in vitro[27].

This study is also in line with research conducted by [17] on the Vanda spatula orchid which is a specific Sri Lanka's orchid and has a very beautiful flower. Callus growth from the flower stalk was produced after 6 months. Multiple shoot formations (6.1 shoot per explant) was produced after 3 to 9 weeks later at the Mira medium added with $75 \mathrm{~g} \mathrm{~L}^{-1}$ banana pulp + 22.2 t0 $44.4 \mu \mathrm{M} \mathrm{BA}+5.7$ to $28.5 \mu \mathrm{M}$ IAA. While the root formation was obtained after shoots were sub-cultured to Mira medium supported with $75 \mathrm{~g} \mathrm{~L} \mathrm{~L}^{-1}$ banana pulp $+5.7 \mu \mathrm{M}$ IAA after 9 weeks after sub cultured. 


\section{CONCLUSIONS}

The best sterilization method to reduce the explant contamination level was method 3 , in which explants were washed with detergent, rinsed with flowing water, soaked in a solution of $0.1 \% \mathrm{v} / \mathrm{v} \mathrm{HgCl}_{2}$ solution for 30 minutes, soaked again in a solution of $10 \% \mathrm{v} / \mathrm{v}$ sodium hypochloride for 20 minutes, then rinsed 3 times with sterile water, before planting, soaked in sterile water added $10 \% \mathrm{v} / \mathrm{v}$ bethadine. This method was able to reduce contamination levels up to $70 \%$ from explants cultured on 5 months after sub cultured on MS medium.

Bacterial contaminants level $(52.22 \%)$ which infected the young leaves of orchid used as explant was higher than fungi contaminant level (30\%). Contamination caused by bacteria was more difficult to eliminate than that caused by fungus.

MS medium supported with $1.00 \mathrm{mg} \mathrm{L}^{-1}$ of 2,4-D concentration generated the highest number of embryogenic callus and the biggest callus diameter $(3.5 \mathrm{~cm})$. The embrygenic callus was characterized by transparent green color callus and friable callus structure.

\section{ACKNOWLEDGMENT}

We would like to thank the Directorate General of Higher Education, Ministry of Education Indonesian Republic that has funded this research through the Fundamental Research Grant 2012-2013 fiscal year.

\section{REFERENCES}

[1] A. Romeida., "Ex situ Concervation Bengkulu Province Orchids : Identification of Orchid Species in Kepahiang Regency," Univerity of Bengkulu, Result Reserch, Bengkulu, Nov 1999.

[2] D. J. Coates, and K.W. Dixon, "Current perspectives in plant conservation biology," Australian Journal of Botany, Vol. 55, pp 187-193, 2007.

[3] P. J. Cribb, S.P. Kell, K.W. Dixon, and R.L Barrett. "Orchid conservation: a global perspective". In: K.W.Dixon, S.P. Kell, R.L. Barrett, and P.J. Cribb eds, "Orchid conservation", Natural History Publications, Borneo, pp 1-24, 2003.

[4] M. M. Hossain, "In vitro Embryo Morphogenesis and Micropropagation of Dendrobium aggregatum Roxb." Plant Tissue Cult. \& Biotech. Vol. 23, No. 2, pp. 241 - 249, December 2013.

[5] S. K. Bhadra and M. M. Hossain, "In vitro Germination and Micropropagation of Geodorum densiflorum (Lam.) Schltr., an Endangered Orchid Species". Plant Tissue Cult, Vol. 13, No.2, pp 165-171, December 2003.

[6] E. Bektas, M. Cüce, and A. Sökmen, "In vitro germination, protocorm formation, and plantlet development of Orchis coriophora (Orchidaceae), a naturally growing orchid species in Turkey", Turkish Journal Of Botany, vol.37, pp.336-342, 2013.

[7] N. Ozhatay, "Europe's medicinal and aromatic plants: their use, trade and conservation". A Traffic Network Report, TRAFFIC International: Cambridge, UK, 2000.

[8] M. A. Clemenets, "Molecular phylogenetic systematics in the Dendrobiinae (Orchidaceae), with emphasis on Dendrobium section Pedilonum”. Telopea, Vol.10, pp 247-298, 2003.
N. Machaka-Houri, M. S. Al-Zein, D. B. Westbury, and S.N Talhouk, "Reproductive success of the rare endemic Orchids galilaea (Orchidaceae) in Lebanon". Turkish Journal of Botany Vol. 3, pp 677-682, 2012.

[9] L. W. Gunawan, Budidaya Anggrek. Penebar Swadaya, Jakarta, 2001.

[10] S. W. Decruse, A. Gangaprasad, S. Seeni, and V.S. Menon, "A protoco; for shoot multiplication from foliar meristem of Vanda spathulata (L.) Spreng", Indian J. Exp. Biol. Vol. 41, No18, pp 924-927, 2003

[11] D. R. Aggraini, 2008. Aneka Tanaman Hias Bangka Belitung yang Menarik. UBB Press (Bangka Flora Society), Bangka Belitung, 2008.

[12] Bengkulu Antara News. BKSDA Bengkulu Tangkarkan Anggrek Pensil. www. Antaranews. Bengkulu. 07-08-2006. Accessed at February $2^{\text {nd }}, 2008$

[13] R. A. Kurniati, A. Purwito, G.A. Wattimena, B. Marwoto, dan Supenti, "Induksi kalus dan bulble serta regenerasi tanaman lili varietas Sorbon dari tangkai sari bunga", J. Hort. Vol. 22, No. 4, pp 303-308, 2012.

[14] A. Romeida, dan L. Yuliasari, "Stimulasi pertumbuhan anggrek silangan Vanda tricolor $x$ Pteroceras palidum pada pemberian Kinetin dan 2,4-D secara in vitro", Un publicated Research Result, 2003.

[15] N. Lang, and N. T. Hang, "Using biotechnological approaches for vanda orchid improvement", Omonrice Vol. 14, pp 140-143, 2006.

[16] S. W. Decruse, A. Gangaprasad, S. Seeni, and V.S. Menon, "Micropropagation and ecorestoration of Vanda spathula and exquisite orchid", Plant Cell, Tissue and Organ Culture Vol. 72 No.2, pp 199-202, 2003

[17] S. Seeni, and P.G. Latha, "Foliar regeneration of endangered Red Vanda (Renanthera imschootiana Rolfe) Orchidase", Plant cell, Tissue and organ Culture Vol. 29, pp 167-172, 1992.

[18] J. Govinden-Soulange, N. Boodia, C. Dussooa, R. Gunowa, S. Deensah, S. Facknath and B. Rajkomar, "Vegetative propagation and tissue culture regeneration of Hibiscus sabdariffa L. (Roselle)". World Journal of Agrcultural Science, Vol. 5, No.5, pp 651-661, 2009.

[19] D. Widiastoety, W. Prasetyo, dan Purbadi, "Pengaruh Bubur Buah Pisang terhadap Pertumbuhan Plantlet Anggrek Phalaenopsis dalam Media Kultur. Makalah Prosiding Seminar Nasional Florikultura, Bogor, 4-5 Agustus $2004: 89$ - 93, 2004.

[20] P. K. Utami, dan B. Ginting, "Media untuk meningkatkan induksi dan pertumbuhan PLBs anggrek Dendrobium", J. Hort, Edisi khusus Vol.1, No.32, pp 32-37, 2007.

[21] P. Guedenon, A. P. Edorh, A. S. Y. Hounkpatin, C. G. Alimba., A. Ogunkanmi., E. G. Nwokejiegbe, and M. Boko, "Acute toxicity of Mercury ( $\mathrm{HgCl} 2)$ to African catfish Clarias gariepinus", Research Journal of Chemical Science, Vol. 2, No. 3, pp 41-45, 2012.

[22] B. Bhattacharjee, and S.M.S. Islam, "Effects of plant growth regulators on multiple shoot induction in Vanda tessellata (Roxb.) Hook. Ex G.Don an endangered medicinal orchid", International Journal of Science and Nature, Vol. 5(4), pp 707-712, 2014.

[23] M. Sofnie, Mulyadi dan Idawati, "Translokasi herbisida 2,4-D-14C pada Gulma tanaman padi sawah pada sistem persawahan", ISDP BP3, Palembang, 2000.

[24] J. Moenandir, Pengantar Ilmu Pengendalian Gulma. Rajawali Press. Jakarta, 1990.

[25] S. Seeni and P. G. Latha. "In Vitro Multiplication and EcoRehabilitation of the Endangered Blue Vanda," Plant Cell, Tissue and Organ Culture, Vol. 61, 2000, pp. 1-8, 2000. http://dx.doi.org/10.1023/A:100644461465

[26] U. Sharma, V. R. Rao, J.S.S. Mohan and A.S. Reddy, "In vitro propagation of Dendrobium microbullon A. Rich - A rare ethnomedicinal herb". Indian Journal of Biotechnology, Vol.6, pp:381-384, 2007. 